\title{
Problematika Manhaj Takfir Muhammad bin Abdul Wahhab (Telaah Kritis dalam Tinjauan Maslahah)
}

\author{
Alwi Bani Rakhman \\ IIQ An-Nur Yogyakarta \\ Email: albannibnurahma@gmail.com
}

\begin{abstract}
Muhammad bin Abdul Wahhab is one of Muslims group leader who promoted the takfir concept as an important part in his religious thought. This article explains his methodology of takfir and its legal implications, then examined critically by using maslahah perpective. This study of the works of Muhammad ibn Abdul Wahhab concludes: First, the methodology of takfir Muhammad bin Abdul Wahhab can be seen through understanding his principle thoughts about Ibadah (worship) and Islam, and also various rules that must be known and implemented related to when takfir can be implemented, such as the terms and barriers of takfir, qiyam alhujjah dan masa'il zahirah dan masa'il khafiyyah. Second, considering the legal implications of takfir, then at that time his concept doesn't fully lead to maslahah 'ammah primarily related to the variety of methods of understanding religion (alQur'an and al-Sunnah).
\end{abstract}


Alwi Bani Rakhman

Problematika Manhaj Takfir Muhammad bin Abdul Wahhab

(Telaah Kritis Dalam Tinjauan Maslahah)

Keywords: Takfir, Maslahah, Islamic Legal Implication of Takfir, Muhammad bin Abdul Wahhab

\begin{abstract}
Abstrak
Muhammad bin Abdul Wahhab merupakan diantara pimpinan kelompok umat muslim yang menjadikan pelaksanaan takfir bagian yang cukup urgen dalam paham keagamaan yang dipegangnya. Artikel ini menguraikan manhaj takfir Muhammad bin Abdul Wahhab serta implikasi hukumnya kemudian ditelaah secara kritis metodologis dengan menggunakan sudut pandang maslahah. Penelitian terhadap berbagai literatur karya Muhammad bin Abdul Wahhab ini menghasilkan beberapa kesimpulan; Pertama, manhaj takfir Muhammad bin Abdul Wahhab dapat dimengerti melalui pemahaman yang didasari atas pokok pikirannya tentangmakna Ibadah dan Islam yang dipegangnya serta berbagai aturan yang harus diketahui dan dilaksanakan berhubungan dengan kapan dan kepada siapa takfir dapat dilayangkan seperti syarat-syarat dan penghalang takfir, qiyam alhujjah dan masa'il zahirah dan masa'il khafiyyah. Kedua, mempertimbangkan implikasi hukum takfir, maka manhaj yang dibangunnya tersebut dalam pada saat itu tidak sepenuhnya mengarah kepada maslahah 'ammah sebagaimana yang dituju oleh syara' terutama terkait dengan beragamnya metode memahami agama (al-Qur'an dan al-sunnah).
\end{abstract}

Kata Kunci: Takfir, Maslahah, Implikasi Hukum Takfir, Muhammad bin Abdul Wahhab

\title{
A. Pendahuluan
}

Salah satu persoalan yang cukup krusial dalam sejarah perjalanan pemikiran Islam adalah perihal status keimanan dan kekufuran seorang. Telah tersebut dalam sejarah kelam umat Muslim, sebagaimana dikemukakan oleh al-Syahrastani dalam al-Milal wa alNihal, bahwa sejak akhir masa shahabat pertikaian sengit diantara mereka menjadi buah bibir dan telah tercatat sebagai zaman al-fitan bagi umat Muslim hingga saat ini. Sebab perdebatan diantara mereka 
tidak hanya dalam permasalahan halal-haram dalam urusan dunia, melainkan sudah pada batas saling mengkafirkan antar sesama Muslim yang tidak jarang berakibat pada pertumpahan darah. Sebut saja misalnya sekelompok kecil umat Muslim yang tergabung dalam barisan perang Shiffin bersama shahabat Ali bin Abi Thalib, yang membelot dari al-Imam al-Haq dan menyatakan bahwa ia dan para pengikunya akan selamanya di neraka karena menurut pandangan kelompok ini sang Imam dan pengikutnya telah melakukan dosa besar, keluar dari agama Allah Swt. dengan berhukum kepada selain dari hukum al-Qur'an dan Sunnah. ${ }^{1}$

Filsafat Yunani yang mulai terserap cukup deras ke bangsa Arab karena penggalakkannya yang dilakukan oleh penguasa Abbasiyah di Baghdad, terutama pada masa Khalifah al-Makmun, telah berpengaruh pada peningkatan daya intelektual kaum Muslimin sehingga membuahkan berbagai macam keilmuan. Maka tidak bisa dihindarkan pula, cara berfikir filosofis ini juga telah merambah kepada mereka yang menggeluti dunia gnostik yang berbasis zawq. Sehingga darinya lahir beberapa praktisi sufisme kenamaan, seperti Abu Mansur alHallaj (w. 922 M) yang masyhur dengan hulul, Ibn 'Arabi (w. 1240 M) dan Ibn Sab'in (w. 1270 M) dengan wihdat al-wujud. ${ }^{2}$ Kondisi seperti ini dipandang oleh Ibnu Taymiyah (w. 1328 M) sebagai ancaman terhadap rusaknya kemurnian aqidah Islam yang berdasarkan pada al-Qur'an dan Sunnah, Tauhid. Maka upaya pelayangan dan pelabelan status 'kafir' menjadi sesuatu yang layak.

Demikian usaha pemurnian yang dilakukan oleh Ibnu Taymiyah mendapatkan respon positif dari banyak ulama. Sehingga gerakan-gerakan puritanian terus berjalan sampai pada masa sekitar empat abad pasca wafatnya Ibnu Taymiyah, lahirlah seorang tokoh penerus gerakan tersebut yang cukup terkenal hingga sekarang dan telah menjadi sebuah paham yang cukup berpengaruh dalam dunia

1 Abu al-Fath Muhammad Abdul Karim al-Syahrastani, al-Milal wa al-Nihal (Beirut: Dar al-Fikr, 2005), hlm. 92.

2 Simuh, Tasawuf dan Perkembangannya dalam Islam (Jakarta: Rajawali Pers, 1997), hlm. 143. 
pemikiran Islam. Ia adalah Muhammad bin Abdul Wahhab (1703-1792 M). Pada masa mudanya, oleh Fazlurrahman disebutkan, ia adalah seorang yang menggeluti bidang tasawuf. Namun menjelang masa dewasanya, setelah begumul dengan karya-karya Ibnu Taymiyah, ia berubah haluan menjadi seorang puritan, penentang tertinggi bidang tersebut pada saat itu terutama di wilayah Arab. Ia menyerang kepercayaan sebagian masyarakat Muslim tentang karamah dan syafa'at Nabi dan para wali. ${ }^{3}$

Dikatakan bahwa di antara sebab berkembang pesatnya paham dan gerakan yang dibawahinya adalah sebab ia telah mendapatkan dukungan dari penguasa salah satu kawasan Arab Tengah pada saat itu dan sekaligus dijadikan sebagai menantunya, yaitu pada masa pemerintahan Muhamamd bin Sa'ud (1714-1818 M) yang berhasil merebut kekuasaan dari Turki Utsmani di tanah Hijaz (Semenanjung Arab). ${ }^{4}$ Dalam perjuangan tersebut Muhammad bin Abdul Wahhab, yang oleh oposisinya disebut sebagai Wahhabiyyah, berupaya untuk memurnikan ajaran Islam yang menurut mereka telah terkontaminasi dengan perihal syirik, bid'ah, khurafat, dan takhayyul. Karena bersekutu dengan penguasa politik, mereka juga menghancurkan Karbala pada tahun 1801 M, merebut Mekkah dan Madinah pada tahun 1803-1804 M. Tahun berikutnya mereka menyerbu Syuriah dan Irak dan melebarkan kekuasaan dari Palmyra hingga Oman. ${ }^{5}$

Jikalau ditilik beberapa karyanya seperti Kitab al-Tawhid dan al-Qawa'id al-Arba', maka setidaknya akan dipahami bahwa permasalahan yang paling krusial sepanjang sejarah keIslaman yaitu takfir, merupakan bagian yang cukup urgen dalam ajaran agama Islam yang dipahaminya. Seperti ini pula yang ditegaskan dalam banyak karya pengikutnya, bahwa praktik menghukumi kafir adalah sesuatu

3 Fazlurrahman, Islam (Chicago: The University Chicago Press, 1979), hlm. 207.

4 Badri Yatim, Sejarah Sosial Keagamaan Tanah Suci: Hijaz (Mekkah dan Madinah) 1800-1925 M (jakarta: Logos Wacana Ilmu), hlm. 103.

5 Philip K. Hitti, History of The Arabs terj. Cecep Lukman Yasin (Jakarta: Serambi Ilmu Semesta), hlm. 948. 
yang masyru'. ${ }^{6}$ Namun sayangnya, apabila 'kufur' dipahami secara sepihak, kemudian mensifati serta melabeli seorang muslim dengan karakter kekufuran tanpa mempertimbangkan pendapat yang diajukan oleh para pakar agama lain dan tidak berdasar pada batasan dan atau aturan yang tegas akan menjadi masalah melihat konsekwensi yang dihasilkan darinya.

\section{B. Biografi Singkat Muhammad bin Abdul Wahhab}

Muhammad bin Abdul Wahhab memiliki nama lengkap Muhammad bin Abd al-Wahhab bin Sulaiman bin Ali bin Muhammad bin Ahmad bin Rasyid bin Buraid bin Muhammad bin al-Masyarraf at-Tamimi al-Hanbali al-Najdi. Kesempatan memiliki kedudukan terpandang di mata masyarakat Arab ini kemudian, di antaranya, menjadi keuntungan tersendiri bagi perjalanan hidup Muhammad terutama dalam melalui masa karir akademik dan dakwah. ${ }^{7}$

Ia dilahirkan pada tahun 1115 H (1701 M) di kampung 'Uyainah yang terletak di wilayah Yamamah dan masih termasuk bagian dari Najd, lebih kurang $70 \mathrm{~km}$ arah barat laut kota Riyadh, ibukota Arab Saudi sekarang. ${ }^{8}$ Najd, meskipun demikian, bukan merupakan wilayah yang terkenal dengan tradisi kesarjanaan Islam maupun gerakan pembaharuan spiriual. ${ }^{9}$ Adapun kondisi keagamaan dapat dipandang dari beberpa anggota keluarga yang dikenal dengan ahl al-

6 Meskipun terdapat beberapa syarat yang harus dipenuhi. Oleh muwahhidun (sebutan bagi pengikut Muhammad bin Abdl Wahhab), mereka menyebutkan sampainya dalil (iqamah al-hujjah) sebagai syarat bolehnya seseorang menyatakan kafir terhadap seorang yang dianggap telah terjatuhi dalil kufur. Namun inipun tidak lepas dari kritikan para ulama yang berseberangan paham; yaitu bahwa mereka (muwahhidun) memilliki dan mengajukan interpretasi kufur dan syirik secara sepihak, tanpa mempertimbangkan dan mempertimbangkan penafsiran ulama lain.

7 Jamal al-Din Zarabozo, The Life, Teachings, and Influence of Muhammad bin Abdul Wahhab (Riyadh: Ministry of Islamic Affairs, Endowments, and Guidance, 2005), hlm. 14.

8 Muhammad bin Jamil Zainu, Da'wah al-Syaikh Muhammad ibn 'Abdul Wahhab baina al-Mu'aridin wa al-Munassifin wa al-Mu'ayyidin (Riyadh: Dar al-Hadis al-Khairiyyah, T.th), hlm. 7.

9 Hamid Algar, Wahhabisme: Sebuah Tinjauan Kritis terj. Rudy Harisyah Alam (Jakarta: Demokrasi project, 2011), hlm. 23. 
'ilm terutama dalam bidang fiqh Hanbali. Sehingga praktis Muhammad memperoleh masa kecil yang berkualitas dalam bimbingan keluarga yang religius. ${ }^{10}$

Muhammad merupakan seorang yang berasal dari kalangan terpelajar di antara masyarakat sekitarnya pada saat itu. Ayahnya, Abdul Wahhab bin Sulaiman, yang merupakan guru pertamanya adalah seorang hakim (al-qadi) bermadzhab Hanbali di wilayah 'Uyaynah. Sedangkan saudaranya, Sulaiman bin abdul Wahhab juga merupakan salah seorang 'alim dan faqih di wilayah tersebut. Sehingga tidak mustahil, sejak usia sepuluh tahun ia telah menghapal al-Qur'an serta mempelajari berbagai bidang keilmuan, baik fiqih, hadis, tafsir, bahkan tasawuf. ${ }^{11}$ Selain itu, Muhammad juga dikenal dengan seorang yang memiliki hafalan yang cukup kuat dan menghabiskan banyak waktu pada masa kecilnya dengan belajar, terutama dengan ayahnya. ${ }^{12}$

Keterpelajaran keluarga tersebut tidak tanpa beban dan masalah. Kondisi politik dan keagamaan yang tidak stabil melatari bangsa dan negara Arab dan sekitarnya pada saat itu memengaruhi banyak hal dalam diri Muhammad khususnya. Dinasti Utsmani menganggap seluruh jazirah Arabia sebagai milik mereka. Namun kenyataannya, mereka tidak memiliki otoritas yang kuat dan konkret di antara sukusuku Badui kecil yang menghuni lanskap kering ini, yang tinggal menyebar di sekitar oasis-oasis serta bertahan hidup sederhana dan seadanya sebagai pedagang dan penggembala. Muhammad bin Abdul Wahhab sebagai seorang yang berwatak keras menarik beberapa pengikut di antara sesama orang Baduinya dan memimpin kelompoknya berkeliling pedesaan menghancurkan tempat-tempat suci karena dianggap telah menjadi objek pemujaan. Muhammad bin

10 Kondisi semacam ini cukup berbeda dengan umumnya masyarakat di sekitarnya yang masih dalam taraf "menengah ke bawah". Jamal al-Din Zarabozo, The Life, Teachings, ..., hlm. 14.

11 Muhammad bin Jamil Zainu, Da'wah al-Syaikh Muhammad ibn 'Abdul Wahhab ..., hlm. 8 .

12 Jamal al-Din Zarabozo, The Life, Teachings ..., hlm. 13. 
Abdul Wahhab mengajarkan bahwa pemujaan terhadap spapun selain Allah Swt adalah penyembahan berhala, syirik. ${ }^{13}$

Tak ayal, keadaan inilah yang mempengaruhi jalan paham dan pergerakan keagamaan Muhammad bin Abdul Wahhab sebagai salah seorang reformis dalam tanggapan, bahwa apa yang perlu diubah, supaya Islam menjadi maju dan bersih seperti umat terdahulu, bukanlah Islamnya melainkan pemahaman umatnya. Menurutnya, inovasi, perubahan, serta penambahan-penambahan dalam peribadatan telah merusak keimanan seorang muslim, sehingga tidak ada lagi yang mempraktikkan Islam yang murni. Apa yang perlu dilakukan kaum muslim adalah menutup rapat pengaruh Barat serta memurnikan ajraran serta ritual peribadatan seperti sedia kala pada masa Nabi Saw dan sahabat beliau.

Demikianlah perjalanan karir dakwah Muhammad bin Abdul Wahhab, hingga suatu ketika masyarakat di tempat tinggal asalnya merasa terusik akan kerasnya sikap keagamaannya dan menuntutnya untuk diturunkan dari jabatan Qadhi. Muhammad pun hijrah menuju wilayah lain yang disebut Dir'iyyah. Penguasa setempat, Muhammad ibn Saud menyambutnya dengan hangat dan bahkan mengakui Muhammad bin Abdul Wahhab sebagai puncak otoritas keagamaan komunitas muslim, dan begitu sebaliknya, sangpendakwah sendiri sepakat untuk mengakui Ibn saud sebagai pimpinan politik umat muslim setempat, amir, dan memerintahkan pengikutnya untuk berjuang bagi dan bersama dirinya. ${ }^{14}$

Kesenjangan antara kaum modern (Arab yang berbaur dengan budaya luar) dan Badui pedalaman semakin memperbesar sekat antara keduanya. Muhammad ibn Saud yang memiliki visi sama, yaitu "menyatukan" suku Arab dalam satu kepemimpinan, melepaskan diri dari kekuasaan Dinasti Usmani, melihat Muhammad bin Abdul Wahhab sebagai promotor sekaligus pendukung akan terwujudnya

13 Tamim Ansary, Dari Puncak Bagdad, Sejarah Dunia Versi Islam terj. Yuliani Liputo (Jakarta: Zaman, 2012), hlm. 405

14 Tamim Ansary, Dari Puncak Bagdad, hlm. 405 
keinginan politisnya, setidaknya dalam pembebasan dua kota terpenting, Madinah dan Mekkah, sebagai jantung keagamaan umat Muslim sedunia. Sementara itu, ia dan para pengikutnya menyebarkan dan menyerukan visi dakwahnya ke berbagai negeri selain di Saudi, yaitu di Inggris, Skotlandia, Amerika Serikat dan bahkan di Indonesia. Paham dan gerakan keagamaan yang dianut adalah purifikasi, upaya memurnikan ajaran agama yang telah terkontaminasi dengan perihal bid'ah, takhayyul, dan bahkan syirik.

Muhammad bin Abdul Wahhab wafat pada akhir bulan Syawal tahun $1206 \mathrm{H}$ atau bertepatan dengan tahun $1792 \mathrm{M}$. Tidak banyak yang menceritakan tentang kondisi keluarganya. Dikatakan bahwa ia menikahi dua puluh muslimah dan meninggalkan sekian banyak anak keturunan selama masa hidupnya hingga akhir hayatnya yang membentang sepanjang hampir seluruh abad $18 \mathrm{M}$. Adapun diantara karya-karyanya yang popular adalah: Kitab al-Tawhid, Kasyf al-Syubhat, Usul al-Iman, Fada'il al-Islam, Salasah al-Usul, Al-Qawa'id al-Arba'ah, Kitab Mufid al-Mustafid fi Kufri Tarik al-Tawhid, Kitabal-Kaba'ir.

Nampaknya Muhammad bin Abdul memang tidak begitu tertarik untuk menulis pemikiran-pemikirannya layaknya Ibnu Taimiyyah sebagai anutan utamanya. Jikalau kita menelaah sekian banyak karyanya, sebagaimana ditemukan saat ini, sebenarnya hanyalah semacam kumpulan artikel yang berisi pokok-pokok pemahaman keagamaannya, terutama mengenai tauhid. Sehingga menjadi wajar jikalau tulisan-tulisan tersebut kemudian dihimpun menjadi Mu'allafat al-Syaikh yang berisi berbagai karya tulis sang pendakwah.

\section{Manhaj Takfir Muhammad bin Abdul Wahhab}

\section{Konsep tentang Ibadah dan Islam}

Dalam menguraikan hal-hal yang berkaitan dengan keislaman, terdapat beberapa pengertian penting yang harus dipahami. Di antaranya adalah konsep pokok dalam agama Islam tentang Ibadah. Ibadah merupakan ism jami', suatu kata yang melingkupi berbagai arti, 
yaitu segala sesuatu, baik berupa ucapan maupun perbuatan, yang diridhai dan disenangi oleh Allah Swt. Akan tetapi makna substansial ibadah, yang dimaksud oleh Muhammad bin Abdul Wahhab adalah tawhid Allah (mentauhidkan Allah). ${ }^{15}$

Disebutkan bahwa perkara terbesar yang diperintahkan oleh Allah adalah 'tauhid', yaitu mengesakan Allah dengan beribadah hanya kepada-Nya. Sebaliknya, larangan terbesar Allah adalah 'syirik', yaitu memohon kepada selain-Nya dengan menyertakan Allah (mengikutsertakan campur tangan selain Allah dalam beribadah kepada-Nya). ${ }^{16}$

Maksud inti dari ibadah dalam ayat-ayat tersebut tidak lain adalah perintah mentauhidkan Allah dan larangan syirik terhadap-Nya. Maka, muslim manapun yang menyimpang dari ketentuan-ketentuan tersebut, ia termasuk seorang musyrik kafir. Diantara macam-macam ibadah yang diperintahkan oleh Allah sebagaimana teruraikan dalam kitab al-Usul al-Salasah adalah al-du'a', al-khauf, al-raja', al-tawakkul, alragbah, al-khusyu', al-khasyyah, al-inabah wa al-isti'anah, al-isti'azah, alistigasah, dan lain-lain. Ayat-ayat yang digunakan sebagai dalil adalah QS. Al-Jin [72]: 18, QS. Al-Mu'minun [23]: 117, QS. Ali Imran [3]: 175, QS. Al-Kahfi ]18]: 110, QS. Al-Thalaq [65]: 3, QS. Al-Anbiya [21]: 90, QS. Al-Fatihah [1]: 5, QS. Al-Anfal [8]: 9. ${ }^{17}$

Sedangkan perihal paling dihindari dalam beribadah adalah tagut. Allah Swt melarang keras umat muslim menyembah tagut. Pengertian yang dipegang Muhammad bin Abdul Wahhab mengenai tagut adalah sebagaimana yang telah diuraikan oleh Ibnul Qayyim;

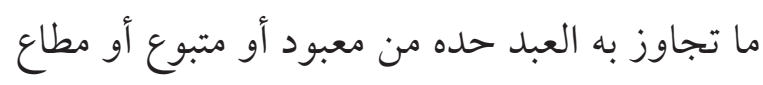

15 Abdurrahman bin Muhammad bin Qasim al-Najdiy, al-Durar al-Saniyyah fi alAjwibah al-Najdiyyah; Majmu'ah Rasa'il wa Masa'il 'Ulama Najd al-A'lam min 'Asr alSyaikh Muh\}ammad ibn Abd al-Wahhab ila 'Asrina Haza Juz II (Riyadh: Maktabah Adhwa' al-Salaf, 1996 M/1417 H), hlm 303 dan 311.

16 Muhammad bin Abdul Wahhab, Al-Usul al-Salasah wa Adillatuha (Riyadh: Wizarah al-Syu'un al-Islamiyyah wa al-Awqaf wa al-Da'wah wa al-Irsyad, $1420 \mathrm{H}), \mathrm{hlm} .3$.

17 Muhammad bin Abdul Wahhab, Al-Usul al-Salasah wa Adillatuha ..., hlm. 4-5. 
Kemudian menurutnya tagut bermacam-macam, dan diantara yang terutama adalah iblis, seseorang yang ia ridhai untuk disembah, seorang yang menyeru kepada manusia supaya disembah, seorang yang mengaku paham tentang perihal ghaib, dan orang yang berhukum dengan selain yang Allah turunkan (al-Qur'an dan Sunnah). ${ }^{18}$ Tatacara kufur terhadap tagut\} menurutnya adalah harus meyakini batalnya ibadah kepada selain Allah Swt, meninggalkannya (tagut), membencinya, serta mensifati kufur (takfir) terhadap ahli tagut serta memusuhinya. ${ }^{19}$

Adapun Islam, menurutnya mengandung arti penyerahan diri hanya kepada Allah dengan jalan bertauhid dan taat kepada-Nya, serta membebaskan diri dari syirik dan ahli syirik. Hal ini tertuang dalam tiga panji penting dan bersifat hierarkis; Islam, Iman, dan Ihsan. Masing-masing dari tingkatan ini juga memiliki arkan. ${ }^{20}$

Muhammad bin Abdul Wahhab, sebagaimana ia dasarkan pada QS Al-Muddassir [74]; 1-7, memandang bahwa perintah Nabi Saw. yang paling utama selama masa dakwahnya adalah untuk mengesakan Allah Swt. dan begitu sebaliknya, larangan paling besar yang harus dijauhi adalah syirik dan kufur terhadap Allah Swt. Perintah Allah Swt. kepada Nabi Saw. untuk bangun berarti bangun dari syirik dan menyeru kepada tauhid, mengagungkan Tuhan berarti mengagungkan-Nya dengan tauhid, mensucikan pakaian berarti menyucikan perbuatan dari syirik, berhijrah berarti hijrah dari negeri syirik menuju negeri Islam supaya terbebas dari syirik dan ahli syirik, dan ini berlaku hingga hari kiamat. ${ }^{21}$

\section{Hal-hal yang Membatalkan KeIslaman Seorang Muslim}

Sebagaimana diketahui bahwa Muhammad bin Abdul Wahhab merupakan seorang pendakwah yang senantiasa membawa misi pemurnian ajaran Islam (purifikasi) dengan jargon tauhid, yang

18 Muhammad bin Abdul Wahhab, Al-Usul al-Salasah wa Adillatuha ..., hlm. 11.

19 Muhammad bin Abdul Wahhab, Majmu'ah Rasa'il fi al-Tawhid wa al-Iman (Riyadh: Jami'ah al-Imam Muhammad ibn Sa'ud, 2005), hlm. 376.

20 Muhammad bin Abdul Wahhab, Al-Usul al-Salasah wa Adillatuha ..., hlm. 5.

21 Muhammad bin Abdul Wahhab, Al-Usul al-Salasah wa Adillatuha ..., hlm. 8-9. 
karenanya ia dan para pengikutnya mengatasnamakan diri sebagai muwahhidun. Sehingga dalam aktivitas keagamaannya kerap kali menyertakan pernyataan atau penjelasan tentang hal-hal yang berbahaya dalam Islam, termasuk yang merusak keislaman seseorang. Ia menjelaskan bahwa hal-hal yang dapat membatalkan keislaman seorang muslim ada sepuluh, ${ }^{22}$ yaitu:

a. Mengadakan persekutuan dalam beribadah kepada Allah (syirik).

b. Menjadikan sesuatu atau seseorang sebagai perantara antara seseorang dengan Allah, yang mana ia memohon atau berdoa serta meminta syafa'at kepadanya.

c. Menolak untuk mengkafirkan orang-orang musyrik atau menyangsikan kekafiran mereka, bahkan membenarkan madzhab mereka.

d. Berkeyakinan bahwa petunjuk selain yang datang dari Nabi Saw lebih sempurna dan lebih baik.

e. Membenci sesuatu yang datang dari Nabi Saw. meskipun hal itu telah diamalkannya. Hal ini berdasar firman Allah Swt QS. Muhammad [47]: 9.

f. Mengolok-olok sebagian dari ajaran agama yang dibawa Nabi Saw., misalnya tentang pahala atau balasan ('iqab) yang akan diterima di akhirat kelak. Hal ini berdasar firman Allah Swt QS. Al-Taubah [9]: 65-66.

g. Melakukan sihir.

h. Mengutamakan orang kafir serta memberikan pertolongan dan bantuan kepada orang musyrik lebih daripada pertolongan dan bantuan yang diberikan kepada umat muslim. Hal ini didasarkan pada firman Allah Swt. QS. Al-Maidah [5]: 51.

22 Artinya bahwa muslim manapun yang dianggap melakukan sepuluh hal ini, maka ia telah kufur terhadap Allah Swt (kafir). Lihat Muhammad bin Abdul Wahhab, al-Rasail alSyakhsiyyah al-Risalah al-Saniyah wa al-Salasun (Riyadh: Jami'ah al-Imam Muhammad ibn Sa'ud, 2005), hlm. 212-214. Lihat juga Muhammad bin Abdul Wahhab, Majmu'ah Rasa'il fi al-Tawhid wa al-Iman ..., hlm. 376. 
i. Berkeyakinan bahwa sebagian muslim tidak harus selalu mengikuti Nabi Saw. serta beranggapan bahwa manusia bisa dengan leluasa keluar dari syariat Nabi Saw. sebagaimana leluasanya Nabi Khidhir dari syari'at Nabi Musa as. Pemahaman ini disandarkan pada firman Allah Swt QS. Ali Imran [3]: 85.

j. Berpaling sepenuhnya dari agama Allah, baik karena ia tidak mau mempelajarinya ataupun karena tidak mau mengamalkannya. Hal ini berdasarkan firman Allah Swt. QS. Al-Sajdah [32]: 22.

Semua ini berlaku baik bagi setiap muslim, baik yang sekadar bercanda maupun tidak, baik yang dalam keadaan ketakutan ataupun tidak saat melakukannya, kecuali seorang yang tertekan atau terpaksa (mukrah). Selain daripada itu, seperti orang yang bodoh, orang yang melakukan takwil, salah dalam memahami ajaran, selama telah sampai hujjah dan tidak sedang dalam pembahasan permasalahan zahirah, maka tidak dapat selamat dari takfir. ${ }^{23}$

\section{Landasan Legalitas dan Syarat Pelaksanaan Takfir}

Adapun takfir menurutnya, sebagaimana ulama lain pada umumnya, merupakan kata transitif (muta'addiy) dari kata dasar kufr, sehingga secara bahasa berarti mengkafirkan. Maka yang dimaksud takfir dalam terminologi Islam adalah mensjustifikasi atau menyifati seorang muslim sebagai kafir, karena telah melakukan atau mengucapkan suatu hal yang menyebabkan ia jatuh pada kekufuran.

Takfir, bagi Muhammad bin Abdul Wahhab, merupakan bagian dari ajaran Nabi Saw sebagai pemegang otoritas bagi umatnya, setelah Allah Swt. artinya keberadaannya tidak dapat dihapus dalam praktek keagamaan umat muslim. Ia mendasari praktek takfir dengan beberapa dalil yang banyak tertuang dalam kitab Mufid al-Mustafid fi Kufr Tarik al-Tawhid. ${ }^{24}$ Di antaranya adalah Q.S. Al-Nisa [4]: 140 dan Q.S. Al-Maidah [5]: 51, Selain itu takfir juga menurutnya telah dipraktikkan

23 Muhammad bin Abdul Wahhab, al-Rasail al-Syakhsiyyah al-Risalah al-Saniyah wa al-Salasun ..., hlm. 214.

24 Muhammad bin Abdul Wahhab, Mufid al-Mustafid fi Kufr Tarik al-Tawhid (Riyadh: Jami'ah al-Imam Muhammad ibn Sa'ud, 2005), hlm. 312. 
oleh beberapa shahabat, yaitu pada masa Khalifah Abu Bakar alShiddiq beserta para sahabat lain yang mengecap kufur dan sekaligus memerangi mereka yang mengaku nabi, melarang serta tidak mau membayar zakat, sebab telah dianggap keluar dari Islam (murtad). ${ }^{25}$ Dalam redaksi lain, adanya manhaj atau aturan pelaksanaan takfir ini bagi Muhammad bin Abdul Wahhab merupakan suatu upaya untuk menentang mereka yang menafikan takfir, yaitu kaum Murji'ah, serta yang mengkafirkan umat muslim yang tidak sepaham dengan kelompok tersebut secara membabi buta tanpa pandang bulu, yaitu kaum Khawarij. ${ }^{26}$

Takfir dalam pemahaman keagamaan Muhammad bin Abdul Wahhab merupakan salah satu tema penting mengingat dominasi materi dakwahnya yang berhubungan dengan permasalahan ketauhidan Berikut adalah syarat-syarat yang dengannya takfir dapat dilaksanakan menurut Muhammad bin Abdul Wahhab. Sebaliknya, apabila syarat serta larangan tersebut tidak terpenuhi, maka takfir menjadi haram untuk dilakukan.

a) Syarat-syarat Takfir

1) Syarat bagi pelaku kufur, yaitu: berakal, balig, dengan sengaja melakukan perbuatan atau melafalkan kata atau kalimat kekufuran, kecuali pada permasalahan zahirah, yang tidak disyaratkan niat atau maksud dari ucapanperbuatan karena kejelasan dalalah atas makna kekufuran, dan berkemampuan untuk melakukan ikhtiyar (kuasa dalam memilih, untuk melakukan atau tidak melakukan perbuatan kufur). ${ }^{27}$

2) Syarat terkait dengan ucapan atau perbuatan kekufuran, yaitu: perbuatan dan atau ucapan tersebut harus ditetapkan

25 Muhammad bin Abdul Wahhab, Kitab al-Tawhid (Riyadh: Jami'ah al-Imam Muhammad ibn Sa'ud, 2005), hlm. 306.

26 Muhammad bin Abdul Wahhab, al-Rasail al-Syakhsiyyah al-Risalah al-Sadisah wa al-Salasun (Riyadh: Jami'ah al-Imam Muhammad ibn Sa'ud, 2005), hlm. 244.

27 Muhammad bin Abdul Wahhab, al-Rasail al-Syakhsiyyah al-Risalah al-Tasi'ah..., hlm. 85 . 
berdasarkan dalil-dalil syar'i (al-Qur'an dan Sunnah Nabi Saw.) bahwa ia termasuk dari perbuatan kufur dan atau syirik besar, perbuatan dan atau ucapan tersebut harus jelas menunjukkan kekufuran, serta tidak mengandung kemungkinan lain selain dari kufur.

Adapun perbuatan-perbuatan yang menyebabkan kufur pelakunya, menurut Muhammad bin Abdul Wahhab adalah sebagaimana telah disebutkan sebelumnya mengenai perkara-perkara yang membatalkan keIslaman seorang muslim. Sedangkan perkataan-perkataan yang menyebabkan kufur pelakunya, adalah: mencela, menghina, atau merendahkan Allah Swt. sebagai Tuhan semesta alam, mencela atau menghina Nabi Muhammad saw. beserta ajarannya atau salah seorang dari para Nabi dan Rasul lainnya, menghina al-Qur'an dan Sunnah sebagai pedoman hidup manusia, mengingkari ajaran-ajaran agama Islam yang harus atau wajib diketahui setiap muslim, melawan atau menolak nusus al-sabitah (al-Qur'an dan Sunnah). ${ }^{28}$

b) Penghalang Pelaksanaan Takfir

Adapun yang dimaksud dengan penghalang di sini adalah segala sesuatu yang apabila terdapat hal-hal tersebut, maka takfir menjadi terlarang untuk dilaksanakan. Sebaliknya apabila larangan tersebut tidak ditemukan, maka takfir menjadi boleh, bahkan wajib untuk dilaksanakan. Penghalang-penghalang tersebut terbagi menjadi tiga macam, yaitu:

a. Penghalang yang terkait dengan pelaku kufur, yaitu suatu keadaan atau kondisi dimana pelaku tersebut dianggap sebagai seorang yang pada hakikatnya tidak melakukan perilaku kufur (gayr mukhtar lahu), seperti belum balig, gila, mukrah (dipaksa), dalam keadaan ketakutan atau bahaya yang menimpa jiwanya,

28 Abdurrahman bin Muhammad bin Qasim al-Najdiy, al-Durar al-Saniyyah fi alAjwibah al-Najdiyyah Juz IX..., hlm 377. 
al-jahl (tidak/belum mengetahui), dan salah dalam ta'wil. Dalam redaksi lain dapat diungkapkan bahwa seorang yang tidak atau belum sampai taklif kepadanya, maka hal tersebut menjadi penghalang untuk melaksanakan takfir terhadapnya. Untuk dua kondisi terakhir, yakni al-jahl dan salah dalam melakukan takwil, hanya berlaku bagi syirik kecil (al-syirk al-asgar). Akan tetapi apabila terjadi salah penakwilan pada perkara syirik besar (al-syirk al-akbar), maka pelaksanaan takfir tidak terhalangi. ${ }^{29}$

b. Penghalang yang terkait dengan perilaku atau perbuatan yang menyebabkan kekufuran, yaitu adanya perbuatan atau perkataan tersebut tidak dilakukan atau diungkapkan secara jelas, serta tidak adanya dalil yang sarih qat'iyy al-dilalah yang menerangkannya.

c. Penghalang dalam penetapan hukum kufur, yaitu bahwa apabila terdapat saksi orang yang tidak adil, maka hasil kesaksianya menjadi gugur, dan pelaksanaan takfir menjadi terhalang atau dilarang.

\section{Qiyam al-H\{ujjah dan Zahirah-Khafiyyah dalam Pelaksanaan Takfir}

\section{a. Qiyam al-H\{ujjah}

Terdapat satu terma penting menurut Muhammad bin Abdul Wahhab dalam syarat penetapan kekufuran seseorang, yaitu qiyam al-hujjah atau bulug al-hujjah atau bulug al-risalah, yaitu sampainya hujjah atau dalil, baik dari al-Qur'an maupun Sunnah. ${ }^{30}$ Maksudnya adalah bahwa ketika seseorang melakukan kekufuran, telah sampai kepadanya risalah kenabian. Artinya, perkara halal dan haram telah jelas berdasar petunjuk dari al-Qur'an dan Sunnah. Apabila seseorang telah mengetahui ajaran syari'at Nabi Saw., serta terpenuhi syaratsyarat yang telah tersebut di atas, melakukan perbuatan kufur, maka jatuhlah takfir terhadapnya. Sebaliknya, apabila hujjah atau risalah belum sampai kepadanya, baik karena saat itu Islam belum datang

29 Abdurrahman bin Muhammad bin Qasim al-Najdiy, al-Durar al-Saniyyah fi alAjwibah al-Najdiyyah Juz IX..., hlm 236.

30 Muhammad bin Abdul Wahhab, al-Rasail al-Syakhsiyyah ..., hlm. 244-245. 
atau karena terdapat di daerah yang tidak terjangkau oleh dakwah Islamiyyah, maka ia tidak berhak untuk dijatuhi takfir.

Pada dasarnya, qiyam al-hujjah di sini adalah pengecualian bagi para pelaku kufur yang terdapat dalam keadaan tertentu, yaitu:

a. Mereka yang hidup pada masa sebelum diutusnya Nabi Muhammad Saw. serta belum mengenal al-Syari'ah alMuhammadiyyah.

Kaitannya dengan hal ini, terdapat penjelasan selanjutnya yang diutarakan oleh Muhammad bin Abdul Wahhab, yaitu apabila seseorang hidup pada masa Jahiliyyah, namun ia melakukan perbuatan syirik sebagaimana kemudian diterangkan oleh Syari'at Muhammad Saw., kemudian mati, maka ia tetap dalam keadaan kafir, tidak pantas untuk didoakan, disedekahi, maupun disembelihkan kurban untuk dihadiahkan kepadanya, sebagaimana pernyataan berikut:

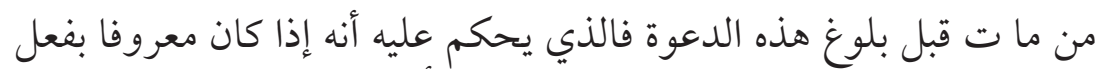

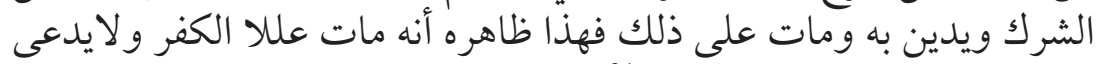

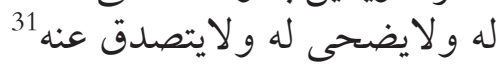

Sebaliknya, apabila syari’at Muhammad belum sampai kepadanya, namun ia sama sekali tidak melakukan perbuatan kufur atau syirik, maka sejatinya ia mati dalam keadaan Islam (muslim). Sehingga berhak untuk didoakan, disholati, dikirim pahala sedekah, kurban, dan haji.

b. Mereka yang hidup di daerah-daerah pedalaman yang jauh dan tidak terjangkau dari syi'ar Islam, serta

c. Mereka yang hidup di zaman dan kawasan yang penuh dengan kebodohan akan ajaran agama serta jauh dari asar al-risalah. ${ }^{32}$

Setelah disebutkan bahwa qiyam al-hujjah merupakan syarat dalam pelaksanaan takfir, berbeda halnya dengan fahm al-hujjah. Karena

31 Abdurrahman bin Muhammad bin Qasim al-Najdiy, al-Durar al-Saniyyah fi alAjwibah al-Najdiyyah Juz I..., hlm 142.

32 Muhammad bin Abdul Wahhab, al-Rasail al-Syakhsiyyah ..., hlm. 244-245. 
ia bukan merupakan syarat, maka paham atau tidak terhadap hujjah yang sampai kepadanya, apabila seseorang jelas melakukan perbuatan kufur, maka jatuhlah takfir terhadapnya. Karenanya, menurut Muhammad bin Abdul Wahhab, seandainya hal tersebut disyaratkan, maka tiada yang akan jelas kekufurannya kecuali hanya orang-orang yang secara terang memusuhi dan melakukan perlawanan terhadap Islam, dan ini merupakan pemahaman yang batil, menurutnya. Maka siapa saja dari orang muslim yang telah mendengar risalah kenabian, h\}ujjah isla>miyyah, dan ia termasuk orang yang berakal dan telah baligh, maka melaksanakan syari'at menjadi wajib baginya. ${ }^{33}$

\section{b. Permasalahan Zahirah dan Khafiyyah dalam Pelaksanaan Takfir}

Membedakan perkara yang jelas (zahir) dan samar (khafiy) dalam menetapkan kekufuran seseorang merupakan hal yang sangat penting dalam proses pelaksanaan takfir. Muhammad bin Abdul Wahhab membedakan keduanya dalam rangka memberikan penjelasan bahwa seseorang yang telah melakukan perkara-perkara berbau syirik dan kufur dalam permasalahan yang jelas, lalu risalah atau hujjah telah sampai kepadanya, maka ia berhak dilabeli sifat kufur atau syirik. Sebaliknya, apabila hanya permasalahan samar saja yang dilakukan, maka ia tidak berhak untuk dijatuhi takfir, kecuali setelah jelas kehujjahan atas perkara tersebut dan tidak ada lagi syubhat. Adapun batasan permasalahan-permasalahan yang jelas menurut Muhammad bin Abdul Wahhab yaitu:

a. Permasalahan tersebut termasuk dalam pembahasan pokok ajaran agama Islam yang urgen, diketahui oleh umat muslim secara umum. Di antaranya adalah perihal perintah tauhid larangan syirik, dan kebenaran risalah kenabian Muhammad Saw.

b. Permasalahan umum yang diketahui umat seluruhnya dan telah disepakati dalilnya secara pasti serta tidak ada lagi syubhat,

33 Abdurrahman bin Muhammad bin Qasim al-Najdiy, al-Durar al-Saniyyah fi alAjwibah al-Najdiyyah Juz X..., hlm 93-94. 
takwil, maupun pencampuradukan pemahaman di dalamnya. Misalnya adalah kewajiban sholat lima waktu, puasa Ramadhan, zakat, haji di makkah, haramnya khamr, zina dan riba.

c. Permasalahan yang sangat jelas lagi masyhur serta telah ditransmisikan secara umum oleh umat muslim awam dari para ulama. Seperti hukum makan dan minum secara sengaja pada siang hari bulan Ramadhan, berbicara dan atau berbincang saat sholat dan sebagainya. ${ }^{34}$

Sedangkan batasan permasalahan-permasalahan yang samar menurut Muhammad bin Abdul Wahhab, yaitu:

a. Permasalahan yang belum banyak diketahui oleh umat muslim pada umumnya secara pasti sebab kesamarannya (dalam pemahaman) maupun tidak tersebarnya berita tersebut kepada khalayak umat. Seperti haramnya menikahi ibu, bibi, kakakadik kandung dan lain-lain.

b. Permasalahan yang masih diperdebatkan diantara para ulama. Disamping juga sebab ketidaktahuan secara pasti hukum yang mesti ditetapkan karena syubhat-syubhat yang dinasabkan kepada al-Qur'an dan Sunnah. Karenanya terjadilah kesalahpahaman, pencampuradukan pemahaman, serta takwil. Seperti ikhtilafnya para ulama dalam menetapkan status kaum Murji'ah dalam bab Iman dan yang lainnya.

c. Permasalahan samar yang tidak dapat diketahui hanya dengan menelaah dalil dari al-Qur'an dan Sunnah, melainkan membutuhkan daya nalar akal dalam memahaminya. Diantara contohnya adalah perihal asma' dan sifat Allah Swt. semisal kata istiwa' dan ru'yat Allah. ${ }^{35}$

34 Abdurrahman bin Muhammad bin Qasim al-Najdiy, al-Durar al-Saniyyah $f i$ alAjwibah al-Najdiyyah Juz II..., hlm 89. Lihat juga Sholih Fauzan, 'Arid al-Juhl (Riyadh: Maktabah al-Rusyd, 1997), hlm 37-39.

35 Abdurrahman bin Muhammad bin Qasim al-Najdiy, al-Durar al-Saniyyah fi alAjwibah al-Najdiyyah Juz II..., hlm 96. 


\section{Telaah Kritis Manhaj Takfir Muhammad bin Abdul Wahhab}

Memang persoalan takfir merupakan bagian dari dinamika pemikiran Islam yang telah menggema sejak abad Islam awal. Namun demikian, pelaksanaannya menjadi sorotan tajam serta bahan diskusi yang serius oleh para ulama, baik salaf maupun khalaf, mengingat implikasi yang dihasilkan sangatlah beresiko, terutama dalam penerapan hukum Islam. Sejauh pembacaan penulis, takfir yang dilakukan tidak pada tempatnya atau kurang tepat dalam menentukan putusan akan kekufuran seseorang, dinilai tidak sejalan dengan semangat tujuan hukum Islam itu sendiri. Dalam Manhaj Takfir alGazali, masalah takfir adalah masalah hukum syar'i. Artinya ketika dinyatakan bahwa seseorang itu kafir, maka pernyataan ini pada dasarnya memiliki tiga implikasi, yaitu:

1. Implikasi hukum akhirat, yaitu masuk neraka selamanya

2. Implikasi hukum dunia, yaitu tidak memiliki hak qisas, tidak berhak menikahi wanita muslimah, tidak dilindungi darah dan hartanya, dan lain sebagainya

3. Implikasi terbunuh karakternya dan dicap sebagai pelaku dusta. ${ }^{36}$

Karena persoalan takfir adalah persoalan hukum syar'i, maka landasan yang benar untuk melakukannya adalah wahyu, bukan akal. Untuk menstigma seseorang sebagai kafir atau muslim, hanya bisa dilakukan dengan pengetahuan dalam al-Qur'an dan al-Hadis atau dalam berijtihad dari kedua sumber hukum Islam tersebut. Menetapkan seseorang sebagai kafir berarti menetapkan kehalalan darahnya bagi dia dan menetapkannya masuk neraka. Kedua hal yang terakhir ini merupakan wilayah hukum syar'i dan hak prerogatif Allah. ${ }^{37}$ Al-Ghazali menambahkan bahwa kekufuran dan kesesatan

36 Abu Hamid Muhammad bin Muhammad al-Ghazali, al-Iqtisad fi al-I'tiqad (Ankara: Nur Matbaasi, 1962), hlm. 246-247. Lihat juga Toshihiko Izutsu, Konsep Kepercayaan dalam Teologi Islam; Analisis Semantik Iman dan Islam (Yogyakarta, Tiara Wacana Yogya, 1994), hlm. 30.

37 Abu Hamid Muhammad bin Muhammad al-Ghazali, al-Iqtisad fi al-I'tiqad, hlm. 246. 
terjadi ketika terjadinya pengingkaran dan pendustaan terhadap Nabi Muhammad Saw. dan ajaran yang dibawanya. Konsep kufur semacam ini sebagai kebalikan dari konsep iman sebagai pembenaran terhadap apa pun yang di bawa oleh Rasullullah. Oleh karena itu yang dimaksud dengan orang kafir adalah siapa saja yang mendustakan terhadap apa pun yang di bawa oleh Rasullullah. ${ }^{38}$

Berdasarkan uraian sementara ulama, setidaknya implikasi hukum takfir dapat dirangkum menjadi dua, yakni berkaitan dengan 'ibadah mahdah dan berkaitan dengan pelaksanaan mu'amalah. Pertama, berkaitan dengan pelaksaan 'ibadah mahdah, maka pelaku yang terlabeli kafir (terkena takfir), menurut sudut pandang hukum Islam tidak diterima seluruh amalannya. Arkan al-Islam sebagai pondasi keagamaan Islam terdiri dari berbagai amal ibadah mahdah yang wajib bagi setiap muslim untuk menegakkannya. Tidak dapat disangkal bahwa syarat diterimanya amal ibadah tersebut yang paling utama adalah harus menyaksikan bahwa tiada tuhan selain Allah Swt dan nabi Muhammad Saw. adalah utusan-Nya. Apabila ia telah memutus dari syarat mutlak ini dengan berbagai hal, baik perkataan atau perbuatan kufur, maka dianggap telah kafir dan atau murtad. Pelebelan kafir terhadap seorang muslim tentu merontokkan seluruh penghargaan yang dijanjikan oleh Allah Swt sebagai ganjaran dari amal ibadah. ${ }^{39}$ Sholat, zakat, puasa, sedekah, haji orang tersebut menjadi tidak bernilai ibadah serta tidak berhak memperoleh pahala. Kedua, berkaitan dengan pelaksanaan mu'amalah, maka terdapat beberapa keberhakan yang tertutup atau terhijab sebab kekufurannya. Terlarang untuk menikahi muslimah, tertutup untuk memperoleh hak waris dan sebagainya. Al-Imam al-Ghazali mengategorikan nikah sebagai ibadah mu'amalah dalam Islam. Poin penting dalam hal ini adalah bahwa jumhur ulama fiqh menyaratkan seorang muslimah hanya boleh menikah dengan muslim. Maka jelas apabila seseorang

38 Abu Hamid Muhammad bin Muhammad al-Ghazali, Faysal al-Tafriqah bayna alIslam wa al-Zandaqah (Tt., $1413 \mathrm{H} / 1993 \mathrm{M})$, hlm. 25.

39 Lihat Yusuf al-Qardhawi, al-'Ibadah fi al-Islam (Kairo: Maktabah Waqfiyyah,1995 M/1416 H), hlm. 93-107. 
telah terhukumi kafir, ia terlarang untuk menikahi seorang muslimah. Orang murtad pun menurut sekian banyak fuqaha' tertolak untuk memperoleh hak waris serta kecil kesempatan untuk diangkat menjadi pimpinan suatu kaum. Demikian implikasi takfir merambah dari urusan 'ibadah mahdah hingga mu'amalah. ${ }^{40}$ Ketiga, berkaitan dengan hubungan serta interaksi sosial antar sesama muslim, setidaknya telah tercoreng nama baik dan mendapat stigma buruk dari muslim lainnya. Secara moral keagamaan, Muhammad bin Abdul wahhab sendiri menguraikan bahwa orang-orang kafir, murtaddin, serta munafiqin wajib hukumnya untuk dimusuhi dan diperangi. Hal ini karena baginya, mereka sudah termasuk dalam kategori musuhmusuh Allah Swt. ${ }^{41}$ Keempat, berkaitan dengan fiqh al-jinayah dan menjadi pertimbangan penting karena menyangkut keberlangsungan hidup manusia adalah terancam terkena hukuman mati (had) -karena bagi yang bertaubat, hukuman mati menjadi dilarang untuk dilakukan. Terakhir inilah yang menjadi perhatian penting terutama kaitannya dengan paham keagamaan Muhammad bin Abdul Wahhab beserta pengikutnya dalam rangka menegakkan dakwah Islamiyyah.

Berdasarkan uraian sebelumnya, maka dapat dikemukakan bahwa manhaj takfir Muhammad bin Abdul Wahhab terbangun berdasar dua poin penting. Pertama melalui pemahaman keagamaannya yang didasari atas pokok pikirannya tentang makna Islam itu sendiri. Islam yang dipegang oleh Muhammad bin Abdul Wahhab sangat kental dengan urusan pemurnian (purifikasi) ajaran dan diekspresikan dengan tindakan yang tegas dan keras. Melihat sejarah awal terbentuknya muwahhidun, upaya pemurnian dilakukan akibat melemahnya kekuatan Islam saat itu di sela-sela ekspansi ekonomi dan budaya bangsa Barat. Muhammad bin Sa'ud sebagai seorang yang memiliki otoritas politik sangat terbuka dengan visi misi keagamaan

40 Abu Hamid Muhammad bin Muhammad al-Ghazali, Ihya' 'Ulum al-Din Jilid II (Beirut: Dar al-Fikr, 2009), hlm. 25. . Lihat juga Jama'ah Ulama Mesir, al-Fiqh 'ala al-Mazahib al-Arba'ah Juz I-II (Istanbul: Maktabah al-Haqiqah, 2004 M/1425 H).

41 Muhammad bin Abdul Wahhab, Mufid al-Mustafid fi Kufr Tarik al-Tawhid..., hlm. 312. 
Muhammad bin Abdul Wahhab untuk menguasai Mekkah dan Madinah sebagai jantung kekuatan umat Muslim yang pada saat itu secara politis masih di bawah kekuasaan Turki Usmani. Selain itu, konflik antar suku juga nampaknya menjadi salah satu pendorong terjadinya pengambilalihan kekuasaan klan Saud atas Turki Usmani dengan dibantu Muhammad bin Abdul Wahhab yang terkenal memiliki banyak pengikut dari suku Arab Badui (natives). Kemudian yang tidak kalah penting adalah bahwa fenomena praktek keagamaan beraliran sufistik yang merajalela di lingkungan Mekkah-Madinah juga memotivasi Muhammad bin Abdul Wahhab untuk bertindak tegas, mengingat sentralitas kedua kota tersebut dalam dunia Islam. ${ }^{42}$

Kedua, melalui berbagai aturan yang harus diketahui dan dilaksanakan berhubungan dengan kapan dan kepada siapa takfir dapat dilayangkan. Maka tersebutlah syarat-syarat dan penghalang takfir, terma qiyam al-hujjah dan masa'il zahirah dan masa'il khafiyyah. Melalui hal tersebut, Muhammad bin Abdul Wahhab diantaranya menjawab berbagai persoalan yang ditujukan kepadanya tentang aturan pelaksanaan takfir. Istilah-istilah tersebut sebenarnya bukan hal baru yang diutarakan oleh Muhammad bin Abdul Wahhab ataupun ulama pengikutnya, melainkan turunan dari apa yang telah dikemukakan oleh pendahulunya, Ibnu Taymiyyah. Meski dikatakan berafiliasi kepada madzhab Ibnu Taymiyyah, namun sebenarnya Muhammad tidak sepenuhnya berkiblat penuh tanpa ada inovasi. Pada ranah dimana ia sangat keras terhadap praktek-praktek atau ritual-ritual yang berbau syirik sebagaimana terjadi di masyarakat Arab pada waktu itu, serta penolakannya terhadap aliran-aliran keagamaan yang dianggapnya melenceng dari ajaran murni Islam, seperti syi'ah, al-asy'ariyyah, dan gerakan-gerakan sufistik inilah yang menjadikannya diangggap sebagai afilliasi terdepan dari madzhab Ibnu Taymiyah. Namun demikian, berbeda dengan wilayah 'garapan' Ibnu Taymiyah yang nampak relatif lebih toleran, yaitu berusaha dengan keras mensyari'atkan tasawuf atau mendudukannya di bawah

42 Tamim Ansary, Dari Puncak Bagdad, Sejarah Dunia Versi ..., hlm. 405. 
payung syari'at secara ketat. Muhammad bin Abdul Wahhab sama sekali tidak mau berkompromi dengan tasawuf dan mengecam keras praktek sufistik karena dianggap biang keladi dari praktek bid'ah dan khurafat, serta tidak jarang jatuh pada kesyirikan. ${ }^{43}$ Ibnu Taymiyyah juga secara terang tidak menolak paham keagamaan yang ditelorkan oleh beberapa sufi terkemuka semisal Abu al-Qasim Junaidi alBaghdadi dan al-Imam al-Ghazali, karena dianggap ajaran mereka berkiblat pada syari'ah muhammadiyyah yang benar. ${ }^{44}$

Selanjutnya, terdapat beberapa hal yang perlu disoroti dalam menganalisa manhaj takfir Muhammad bin Abdul Wahhab. Pertama, terkait dengan beberapa produk pemahaman dari ketentuan takfir, berupa perbuatan-perbuatan yang menjadikan pelakunya seorang kafir (al-af'al al-mukaffirah). Permasalahan yang saat ini muncul diantaranya adalah bahwa metode pengambilan hukum (istinbat\} alahkam) ulama sangat beragam, setidaknya terdapat tiga corak model; zahiriyyah (skriptualis), batiniyyah (rasionalis/liberal), dan mutawassit\} antara zahiriyyah dan batiniyyah. Dalam kaitan tersebut, Dr. Yusuf alQardhawiy membuat postulasi 1 banding 9. Artinya, hanya 10 persen teks ajaran suci (al-Qur'an maupun al-Hadits) yang tak dapat diganggu gugat karena berupa diktum-diktum aturan qath'iy yang konstan dan immutable. Sementara selebihnya (90 persen teks ajaran) berupa aturan-aturan operasional yang bersifat $d z$ anniy dan adaptable..$^{45}$

Adapun Muhammad bin Abdul Wahhab, bahkan, menyatakan bahwa siapa saja yang menyangsikan kekufuran seseorang yang telah diputuskan menjadi kafir, maka ia juga termasuk orang kafir. Sedangkan kemusyrikan yang dipahami oleh Muhammad bin Abdul Wahhab memiliki karakteristik yang berbeda dengan yang dikemukakan oleh ulama lain. Artinya, seseorang yang menurut Muhammad bin Abdul

43 Masyharuddin, Pemberontakan Tasawuf; Kritik Ibnu Taymiyah atas Rancang Bangun Tasawuf (Kudus: STAIN Kudus Press, 2007), hlm. 75-77.

44 Ibnu Taymiyyah, Majmu' Fatawa Juz 35 dalam al-Maktabah al-Syamilah al-Isdar al-Sani. 2002, hlm. 99.

45 Yusuf Al-Qardhawi, Al-Ijtihad wa al-Tajdid bayna al-Dawabit al-Syar'iyyah wa alHayah al-Mu'asirah. (Kairo: Majallat al-Ummah. No. 45. 1985), hlm. 75 
Wahhab adalah kafir atau musyrik, belum tentu menurut ulama lain dikatakan demikian. Sebab kriteria kekufuran ulama berbeda satu dengan yang lainnya kecuali hal-hal yang bersifat pokok dan prinsipil. Maka tidak heran, inovasi-inovasi dalam beragama yang ia temui dalam perjalanan karir dakwahnya secara otomatis dianggap sebuah penyimpangan dalam beragama. Ini menjadi persoalan yang cukup rumit, mengingat umat muslim sangatlah beragam dilihat dari sudut pandang perbedaan mereka dalam memahami teks-teks keagamaan, yang berujung pada perbedaan praktik keagamaan. Karena akan menjadi bermasalah, misalnya, ketika sebuah negara yang menggunakan asas demokrasi dan undang-undang positif dalam berhukum dikatakan sebagai negara kafir dan rakyatnya juga disebut sebagai kuffar hanya karena ia dianggap tagut, meskipun oleh berbagai kalangan cendekia dikatakan bahwa regulasi tersebut telah memuat unsur-unsur Islami.

Kemudian persoalan tentang sihir, misalnya, Muhammad bin Abdul Wahhab dikenal tidak ada kompromi dengan seseorang yang dianggap telah melakukan perbuatan sihir. Orang yang melakukan sihir menurutnya boleh untuk dibunuh tanpa harus menyuruhnya untuk bertaubat terlebih dahulu. Hal ini menurutnya, karena ilmu sihir tidak mampu dihapus dengan taubat. Selain itu, para penyihir berusaha untuk menciptakan kerusakan di bumi, kerusakan yang sangat besar dan sangat berpotensi untuk menyebar ke seluruh penjuru bumi. Maka membunuhnya secara langsung menjadi wajib. Berbeda halnya dengan banyak ulama lain yang mengatakan bahwa penyihir juga wajib diberi kesempatan untuk bertaubat terlebih dahulu. Sebab secara hirarkis, ia menempati posisi di bawah murtad. Adapun seorang murtad saja masih diberi kesempatan untuk bertaubat, maka semestinya penyihir memiliki kesempatan lebih daripada murtad.

Permasalahan takfir ini, meski termaktub dalam dua pedoman tertinggi umat Islam, namun penyelenggaraannya dalam kehidupan nyata harus memiliki aturan serta batasan yang jelas dan tegas. 
Tamim Ansary, salah satu tokoh sejarawan muslim kontemporer, menyebutkan pada tahun 1802, Aziz bin Muhammad bin Saud (putera sekaligus amir pengganti Muhammad bin Saud) melalui otoritas keagamaan warisan Muhammad bin Abdul Wahhab menaklukkan kota Karbala dan membunuh sekitar dua ribu penduduk Syiah di sana yang saat itu sedang berkumpul memperingati kesyahidan Hussein..$^{46}$ Motif pembunuhan dari sudut pandang keagamaan versi ajaran Muhammad bin Abdul Wahhab jelas, bahwa penduduk Syiah dianggap telah keluar dari agama Islam. Sehingga darahnya halal dan hartanya berhak untuk dirampas. ${ }^{47}$

Pemahaman serta penerapan takfir Muhammad bin Abdul Wahhab, menurut hemat penulis, termasuk dari golongan yang sangat ketat (tasyaddud) jikalau tidak berkenan untuk mengatakan berlebihan (al-guluw). Ketat dalam arti sangat sulit untuk 'menyelamatkan' seseorang yang dituduh telah melakukan dan atau mengatakan suatu hal yang menjatuhkannya pada kekufuran untuk kembali kepada keIslaman (istitab). Sebaliknya, ia nampak lebih memudahkan untuk menjustifikasi kekufuran seseorang yang menurut ulama lain masih membutuhkan klarifikasi lebih mendalam. Keputusan untuk mempermudah pelaksanaan takfir ini tentu tidak sejalan dengan maslahah 'ammah yang telah dibangun oleh sementara ulama. Karena ini menyangkut dengan inklusifitas ajaran agama Islam serta heterogenitas umat muslim di dunia. ${ }^{48}$ Terkait hal ini perlu dikemukakan uraian apik dari Al-Ghazali, ia merinci maslahah pada lima konsep dasar hukum; [1] keselamatan keyakinan agama masing-

46 Menurut kacamata politik memang menjadi suatu hal yang wajar pada waktu itu; melakukan pembantaian saat melakukan penaklukkan dan perluasan wilayah kekuasaan. Namun yang menjadi perhatian adalah bahwa dasar kuat yang menjadi semakin gencarnya upaya tersebut adalah seruan pemahaman ajaran Islam oleh kelompok mereka yang notabene warisan dari ajaran yang dibawa dan didakwahkan oleh Muhammad bin Abdul Wahhab, meski saat itu ia telah meninggal. Tamim Ansary, Dari Puncak Bagdad, Sejarah Dunia Versi Islam terj. Yuliani Liputo (Jakarta: Zaman, 2012), hlm. 408.

47 Tamim Ansary, Dari Puncak Bagdad, Sejarah Dunia Versi Islam, hlm. 411.

48 Abd al-Wahhab Khallaf, Masadir al-Tasyri' al-Islamiy fima La Nassa fihi (Kuwait: Dar-al-Qalam, 1392 H/ 1972 M), hlm. 80. 
masing tanpa ada paksaan untuk piadah agama; [2] keselamatan fisik dari tindakan badani; [3] kebebasan berfikir dan berekspresi dari intimidasi; [4] keselamatan keluarga dan sanak-keturunan; [5] keselamatan harta benda. ${ }^{49}$

Hal ini semua tidak lain adalah karena melihat kemaslahatan bagi umat muslim secara luas yang notabene terdiri dari berbagai kelompok, heterogen, yang berbeda madzhab penafsiran serta pengamalan terhadap ajaran-ajaran yang tertuang dalam al-Qur'an dan sunnah. Semuanya bersumber dari dua pedoman utama tersebut karena keduanya pusaka utama bagi umat muslim. Harus diakui dan diterima bahwa pada setiap peristiwa hukum yang muncul di tengahtengah masyarakat tidak tertutup kemungkinan terdapat beberapa anasir kandungan hukum yang tidak tunggal. Perbedaan seperti ini bukan saja disebabkan tingkat kemampuan Mujtahid yang tidak sama antara yang satu dengan yang lain dalam bergumul dengan proses pencarian makna teks, tetapi juga amat dipengaruhi konteks perbedaan ruang dan waktu. Selain itu juga berdasar pada kenyataan akan terbatasnya jumlah teks wahyu jika dibandingkan dengan jumlah peristiwa hukum yang terus berkembanag seiring perkembangan waktu. Namun demikian -meminjam redaksi Prof. M. Quraish Shihab-, al-Qur'an itu layaknya permata, yang dilihat dari sisi manapun tentu tetap indah. Artinya, semestinya bagi seorang 'alim memahami bahwa dalam beragama (baca: memahami nusus al-syari'ah) terdapat kesempatan untuk mendalami ayat-ayat tertentu serta membacanya dengan sudut pandang yang berbeda, namun harus memiliki semangat atau ruh yang sama, demi tegaknya Islam. ${ }^{50}$

Kedua, ulama pun masih berbeda pendapat mengenai permasalahan zahirah dan khafiyyah. Artinya, dalam permasalahan yang jelas (zahir) pun masih terdapat kesempatan kompromi pendapat

49 Abu Hamid Muhammad bin Muhammad al-Ghazali, Al-Mustasfa min 'Ilm al-Usul Juz I. (Beirut: Mu'assasat al-Risalah, 1417 H/1997 M.), hlm. 278.

50 M. Quraish Shihab, Membumikan Al-Qur'an; Fungsi dan Peran Wahyu dalam Kehidupan Masyarakat. (Bandung: Mizan, 1994), hlm. 16 
antar ulama. Adapun Muhammad bin Abdul Wahhab menegaskan bahwa bagi siapa saja yang berbuat kufur dalam permasalahan yang zahirah, maka ia wajib dijatuhi takfir. Sekalipun ia tidak sengaja dalam mengucapkan atau melakukannya (mukhti') atau salah dalam takwil, atau tidak mengetahui akan kebenaran yang pasti (jahil). Ibnu Taymiyah mengemukakan bahwa kesalahan (al-khata') ulama dalam berijtihad sama sekali tidak mampu untuk menjadi dasar takfir kepada mereka, bahkan ini (takfir kepada ulama sebab kesalahan mereka dalam berijtihad) disebut sebagai kemungkaran yang pelakunya berhak untuk mendapatkan 'uqubah. Karena jikalau berlaku, maka akan banyak sekali ulama dari golongan al-Syafi'iyyah, al-Malikiyyah, al-Hanafiyyah, al-Hanabilah, al-Asy'ariyyah, ahl al-Hadis dan al-Tafsir, al-Sufiyyah..$^{51}$

Pembacaan serta pemahaman nas\} syar'iy secara tekstual dalam keadaan tertentu memicu jatuhnya takfir dengan relatif mudah. Hal ini penulis kira, selain karena eksklusifitas paham keagamaannya, juga karena dalam setiap paham keagamaann yang Muhammad bin Abdul Wahhab bawa selalu dikaitkan dengan permasalahan syirk dan bid'ah. Makna ibadah yang diusungnya selalu terikat dengan persoalan kufur dan syirik. Beberapa pelaku yang ulama masih berbeda pendapat akan penentuan kekufurannya, atau minimal masih diberi kesempatan untuk bertaubat, seperti pada persoalan penyihir, menurut hemat penulis, perlu dipertimbangkan kembali kemaslahatannya. Karena dalam hal tertentu tidak selaras dengan prinsip-prinsip nilai maslahah yang dijunjung tinggi oleh agama, dan tidak menutup kemungkinan akan terulang kembali sejarah kelam zaman al-fitan. Syari'ah Islam menjunjung tinggi prinsip-prinsip keadilan (al-'adl) dan kasih sayang (al-rahmah) terhadap ummat (Muslim), bahkan sesama manusia. Dari sini semakin mempertegas jarak antara pola pemikiran Muhammad bin Abdul Wahhab dengan anutannya, Ibnu Taymiyyah. Karena menurut nalar analitiknya, Ibnu Taymiyyah memiliki pandangan

51 Ibnu Taymiyyah, Majmu' Fatawa Juz 20 dalam al-Maktabah al-Syamilah al-Isdar al-Sani. 2002, hlm. 474. 
yang cukup kentara dalam mewujudkan tatanan kemanusiaan yang egalitarian, karena ini menurutnya adalah manifestasi syar'i. Ia berpedoman bahwa misi yang diemban oleh syariat adalah misi kemanusiaan yang harus direalisasikan dalam praksis kehidupan manusia yang aksentuasenya pada ranah humanitas yang paripurna. ${ }^{52}$ Lebih jauh lagi Ibnu Qayyim al-Jawziyyah mengemukakan,

“Tidak sedikit orang yang karena sedikitnya keilmuan yang dimiliki terjerembab ke dalam lembah kekeliruan yang mendasar mengenai ajaran syariat. Mereka menjerumuskan diri ke dalam kesempitan dan kesukaran serta bersikeras memaksakan untuk menerapkan hukum yang semestinya tidak ada akses untuk diterapkan. Syari'at Islam bersdiri di atas fondasi kebijaksanaan dan kepentingan hidup umat manusia di dunia dan akhirat. Secara keseluruhan, syari'at Islam bercirikan keadilan, rahmah, maslahah dan hikmah. Karena itu, setiap masalah yang menyimpang dari sifat keadilan menuju kezaliman, dari rahmah menuju adzab, dari maslahah menuju mafsadah, dari hikmah menuju kesia-siaan, maka masalah tersebut tidaklah termasuk dalam lingkaran syari’at Islam walaupun dipaksapaksakan untuk dimasukkannya dengan jalan $t a^{\prime}$ wil $^{6.53}$

\section{E. Kesimpulan}

Berdasarkan uraian di atas dapat disimpulkan bahwa manhaj takfir Muhammad bin Abdul Wahhab dapat teruraikan dalam dua poin. Pertama melalui pemahaman yang didasari atas pokok pikirannya tentang Islam itu sendiri. Islam yang dipegang oleh Muhammad bin Abdul Wahhab sangat kental dengan urusan pemurnian (purifikasi) ajaran dan diekspresikan dengan tindakan yang tegas dan keras, sehingga menjadi wajar apabila takfir serta istilah-istilah yang terkait dengan seperti kufr dan syirik kerapkali menjadi materi utama dalam

52 Ibnu Taymiyyah, Majmu' Fatawa Juz 35 dalam al-Maktabah al-Syamilah al-Isdar al-Sani. 2002, hlm. 48.

53 Ibnu al-Qayyim al-Jawziyyah, I'lam al-Muwaqi' in 'an Rabb al- 'Alamin Juz V (Kairo: Dar al-Hadis, 1425 H/2004 M), hlm. 5 
berdakwah. Kedua, melalui berbagai aturan yang harus diketahui dan dilaksanakan berhubungan dengan kapan dan kepada siapa takfir dapat dilayangkan seperti syarat-syarat dan penghalang takfir, qiyam al-hujjah dan masa'il zahirah dan masa'il khafiyyah. Melalui hal-hal tersebut, Muhammad bin Abdul Wahhab menjawab berbagai persoalan tentang aturan pelaksanaan takfir.

Kemudian manhaj tersebut tentu tidak terbebas dari kelemahan dan atau kekurangan layaknya ijtihad lainnya dalam menentukan kaidah berhukum untuk aplikasi praktek keagamaan. Beberapa permasalahan keagamaan yang masih diperdebatkan oleh ulama dianggap telah final, selesai pembahasannya pada apa yang dilafalkan oleh teks (al-Qur'an maupun Sunnah). Sedangkan permasalahan tersebut, menurutnya, berimbas pada jatuhnya seorang muslim pada kekufuran. Hal ini mengisyaratkan bahwa apa yang dibangun oleh Muhammad bin Abdul Wahhab dalam konsep takfirnya dalam pada saat itu tidak sepenuhnya mengarah kepada maslahah 'ammah sebagaimana yang dituju oleh syara' terutama terkait dengan beragamnya metode memahami agama (al-Qur'an dan al-sunnah) dan tidak menutup kemungkinan hal ini akan memicu terulang kembalinya sejarah kelam zaman al-fitan. Melihat fenomena keagamaan ini -dan terlihat sudah mulai marak di seluruh penjuru dunia- penulis nampaknya sangat berkepentingan untuk menyuarakan perlunya digalakkan kembali gagasan figh al-ikhtilafsebagai upaya untuk menyatukan kesepahaman akan keberbedaan tersebut sehingga tercapai al-i'tilaf seluruh umat.

\section{Daftar Pustaka}

Algar, Hamid. Wahhabisme: Sebuah Tinjauan Kritis terj. Rudy Harisyah Alam. Jakarta: Demokrasi Project, 2011.

Ansary, Tamim. Dari Puncak Bagdad, Sejarah Dunia Versi Islam terj. Yuliani Liputo. Jakarta: Zaman, 2012. 
Asmawi. Aplikasi Maslahah dalam Kriminalisasi Pencucian Uang, Makalah dalam "Seminar Ilmiah Dosen" di UIN Sunan Gunung Djati Bandung, 2009.

Fauzan, Sholih. 'Arid al-Juhl. Riyadh: Maktabah al-Rusyd, 1997.

Fazlurrahman. Islam. Chicago: The University Chicago Press, 1979.

al-Ghazali, Abu Hamid Muhammad bin Muhammad. Al-Mustasfa min

'Ilm al-Usul Juz I. Beirut: Mu'assasat al-Risalah, 1417 H/1997 M. . Faysal al-Tafriqah bayna al-Islam wa al-Zandaqah. 1413

H/1993 M. . al-Iqtisad fi al-I'tiqad. Ankara: Nur Matbaasi, 1962. . Ih\}ya' 'Ulum al-Din Jilid II. Beirut: Dar al-Fikr, 2009.

Hitti, Philip K. History of The Arabs terj. Cecep Lukman Yasin. Jakarta: Serambi Ilmu Semesta, 2005.

Idamy, Dahlan. Karakteristik Hukum Islam. Surabaya: Al-Ikhlas, 1994. Izutsu, Toshihiko. Konsep Kepercayaan dalam Teologi Islam; Analisis Semantik Iman dan Islam. Yogyakarta, Tiara Wacana Yogya, 1994. al-Ifriqiy, Jamal al-Din Muhammad ibn Mukarram ibn Manzur. Lisan al-'Arab Juz II. Riyadh: Dar 'Alam al-Kutub, 1424 H/2003 M.

al-Jawziyyyah, Ibnu Qayyim. I'lam al-Muwaqi'in 'an Rabb al-'Alamin Juz V. Kairo: Dar al-Hadis, 1425 H/ 2004 M)

Jama'ah Ulama Mesir. al-Fiqh 'ala al-Mazahib al-Arba'ah Juz I-II (Istanbul: Maktabah al-Haqiqah, 2004 M/1425 H).

Khallaf, Abd al-Wahhab Masadir al-Tasyri' al-Islamiy fima La Nassa fihi. Kuwait: Dar-al-Qalam, 1392 H/ 1972 M.

Masyharuddin. Pemberontakan Tasawuf; Kririk Ibnu Taymiyah atas Rancang Bangun Tasawuf. Kudus: STAIN Kudus Press, 2007.

al-Najdiy, Abdurrahman bin Muhammad bin Qasim. al-Durar alSaniyyah fi al-Ajwibah al-Najdiyyah; Majmu'ah Rasa'il wa Masa'il 'Ulama Najd al-A'lam min 'Asr al-Syaikh Muhammad ibn Abd al- 
Wahhab ila 'Asrina Haza Juz II. Riyadh: Maktabah Adhwa' al-Salaf, $1996 \mathrm{M} / 1417 \mathrm{H}$.

al-Qardhawi, Yusuf. al-'Ibadah fi al-Islam. Kairo: Maktabah Waqfiyyah,1995 M/1416 H.

. Madkhal li Dirasat al-Syari'ah al-Islamiyyah. Kairo:

Maktabah Wahbah, 1990. - Al-Ijtihad wa al-Tajdid bayna al-Dawabit al-Syar'iyyah wa al-Hayah al-Mu'asirah. Kairo: Majallat al-Ummah. No. 45. 1985. al-Raisuni, Ahmad. al-Ijtihad bain al-Nass wa al-Waqi' wa al-Maslahah. Damaskus: Dar al-Fikr, 1422 H/2002 M.

al-Salam, Izz al-Din ibn 'Abd. Qawa'id al-Ahkam fi Masalih al-Anam Juz

V. Kairo: Maktabah al-Kulliyyat al-Azhariyyah, 1994.

al-Syahrastani, Abu al-Fath Muhammad Abdul Karim. al-Milal wa alNihal. Beirut: Dar al-Fikr, 2005.

Taymiyah, Ibnu. Fatawa al-Kubra Juz II. Beirut: Dar al-Kutub alIlmiyyah, 1987. . Majmu' Fatawa Juz 35 dalam al-Maktabah al-Syamilah al-Isdar al-Sani. 2002.

. Majmu' Fatawa Juz 20 dalam al-Maktabah al-Syamilah al-Isdar al-Sani. 2002.

Shihab, M. Quraish. Membumikan Al-Qur'an; Fungsi dan Peran Wahyu dalam Kehidupan Masyarakat. Bandung: Mizan, 1994.

Simuh. Tasawuf dan Perkembangannya dalam Islam. Jakarta: Rajawali Pers, 1997.

Wahhab Muhammad bin Abdul. Al-Qawa'id al-Arba'. Riyadh: Wizarah al-Syu'un al-Islamiyyah wa al-Awqaf wa al-Da'wah wa al-Irsyad, $1420 \mathrm{H}$.

. Kitab al-Tawhid. Riyadh: Jami'ah al-Imam Muhammad ibn Sa'ud, 2005. 
al-Rasail al-Syakhsiyyah al-Risalah al-Sadisah wa al-

Salasun. Riyadh: Jami'ah al-Imam Muhammad ibn Sa'ud, 2005. Al-Usul al-Salasah wa Adillatuha. Riyadh: Wizarah alSyu'un al-Islamiyyah wa al-Awqaf wa al-Da'wah wa al-Irsyad, 1420 H.

. Majmu'ah Rasa'il fi al-Tawhid wa al-Iman. Riyadh:

Jami'ah al-Imam Muhammad ibn Sa’ud, 2005. - Mufid al-Mustafid fi Kufr Tarik al-Tawhid. Riyadh: Jami'ah al-Imam Muhammad ibn Sa'ud, 2005.

Yatim, Badri Sejarah Sosial Keagamaan Tanah Suci: Hijaz (Mekkah dan Madinah) 1800-1925 M. Jakarta: Logos Wacana Ilmu, Tth.

Zaid, Mustafa. al-Maslahah fi al-Tasyri'al-Islamiy wa Najm al-Din al-Tufi. Beirut: Dar al-Fikr al-'Araby, 1384 H/1964 M.

Zainu, Muhammad bin Jamil. Da'wah al-Syaikh Muhammad ibn 'Abdul Wahhab baina al-Mu'aridin wa al-Munassifin wa al-Mu'ayyidin. Riyadh: Dar al-Hadis al-Khairiyyah, T.th.

Zakariya, Abu al-Husain Ahmad ibn Faris ibn. Mu'jam Maqayis alLugah Juz III. Kairo: Maktabah al-Khanji, 1403 H/1981 M.

Zarabozo, Jamal al-Din. The Life, Teachings, and Influence of Muhammad binAbdulWahhab. Riyadh: Ministry of Islamic Affairs, Endowments, and Guidance, 2005.

al-Zuhaili, Wahbah. al-Fiqh Al-Islami wa Adillatuh juz VII. Damaskus: Dar al-Fikr. Tt. 